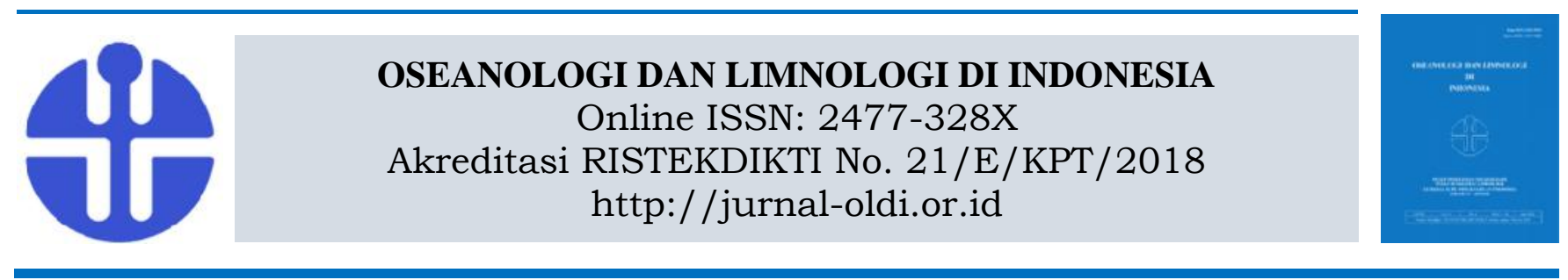

\title{
Distribusi Logam Berat Dalam Air Laut Dan Sedimen Di Perairan Cimanuk, Jawa Barat, Indonesia
}

\author{
Harmesa ${ }^{*}$, Lestari $^{1}$, dan Fitri Budiyanto ${ }^{1}$ \\ ${ }^{1}$ Pusat Penelitian Oseanografi LIPI \\ Jl. Pasir Putih 1 No. 1 Ancol Timur, Jakarta 14430 \\ *Email: harmesa@lipi.go.id
}

Submitted 5 March 2020. Reviewed 23 March 2020. Accepted 9 April 2020.

DOI: 10.14203/oldi.2020.v5i1.310

\begin{abstract}
Abstrak
Aktivitas perekonomian yang terus meningkat di wilayah pesisir utara Jawa, berpotensi menyumbangkan kontaminan antropogenik yang mengancam kualitas perairan pesisir dan estuari Cimanuk di Indramayu. Logam berat yang merupakan salah satu limbah dari aktifitas tersebut belum dipelajari secara terperinci. Penelitian ini bertujuan untuk menentukan distribusi dari logam $\mathrm{Cu}, \mathrm{Pb}, \mathrm{Cd}, \mathrm{Zn}$, dan $\mathrm{Ni}$ yang terlarut dalam air laut dan dalam sedimen di Estuari Cimanuk. Pengambilan sampel air laut dan sedimen dilakukan pada Bulan Mei 2017 di 18 stasiun. Sampel air laut diekstraksi menggunakan metode ektraksi balik (back extraction) sementara sampel sedimen diekstraksi menggunakan asam sesuai metode USEPA 3050B. Pengukuran logam berat dari ekstrak air laut ataupun sedimen dilakukan menggunakan Flame Absorption Spectrophotometry berdasarkan metode USEPA 3050B. Distribusi spasial logam berat dalam air laut dan sedimen dimodelkan menggunakan $\operatorname{ArcGIS}{ }^{\circledR}$ versi 10.6.1. Hasil penelitian menunjukkan konsentrasi logam terlarut dalam air laut untuk $\mathrm{Cu}, \mathrm{Pb}, \mathrm{Cd}, \mathrm{Zn}$, dan $\mathrm{Ni}$ adalah $0,0004-0,0038 \mathrm{mg} / \mathrm{L}(\mathrm{Cu})$, $<0,0001-0,0044 \mathrm{mg} / \mathrm{L}(\mathrm{Pb}), 0,0002-0,0003 \mathrm{mg} / \mathrm{L}(\mathrm{Cd}), 0,0005-0,0119 \mathrm{mg} / \mathrm{L}(\mathrm{Zn})$, dan 0,0020 - 0,0052 $\mathrm{mg} / \mathrm{L}(\mathrm{Ni})$. Konsentrasi logam dalam sedimen adalah $12,36-54,08 \mathrm{mg} / \mathrm{kg}(\mathrm{Cu}), 6,43-15,72 \mathrm{mg} / \mathrm{kg}(\mathrm{Pb})$, $0,07-0,37 \mathrm{mg} / \mathrm{kg}(\mathrm{Cd}), 64,53-85,16 \mathrm{mg} / \mathrm{kg}(\mathrm{Zn})$, dan 19,66 - 62,85 mg/kg (Ni). Model distribusi spasial menunjukkan bahwa logam berat dalam air laut maupun sedimen menunjukkan pola yang identik. Logam dengan konsentrasi tinggi umumnya terdeteksi di stasiun yang berlokasi dekat dengan daratan, mengindikasikan bahwa logam berat mengalami pengayaan yang berasal dari aktivitas antropogenik daratan.
\end{abstract}

Kata kunci: logam berat, aktivitas antropogenik, Cimanuk, air laut, sedimen.

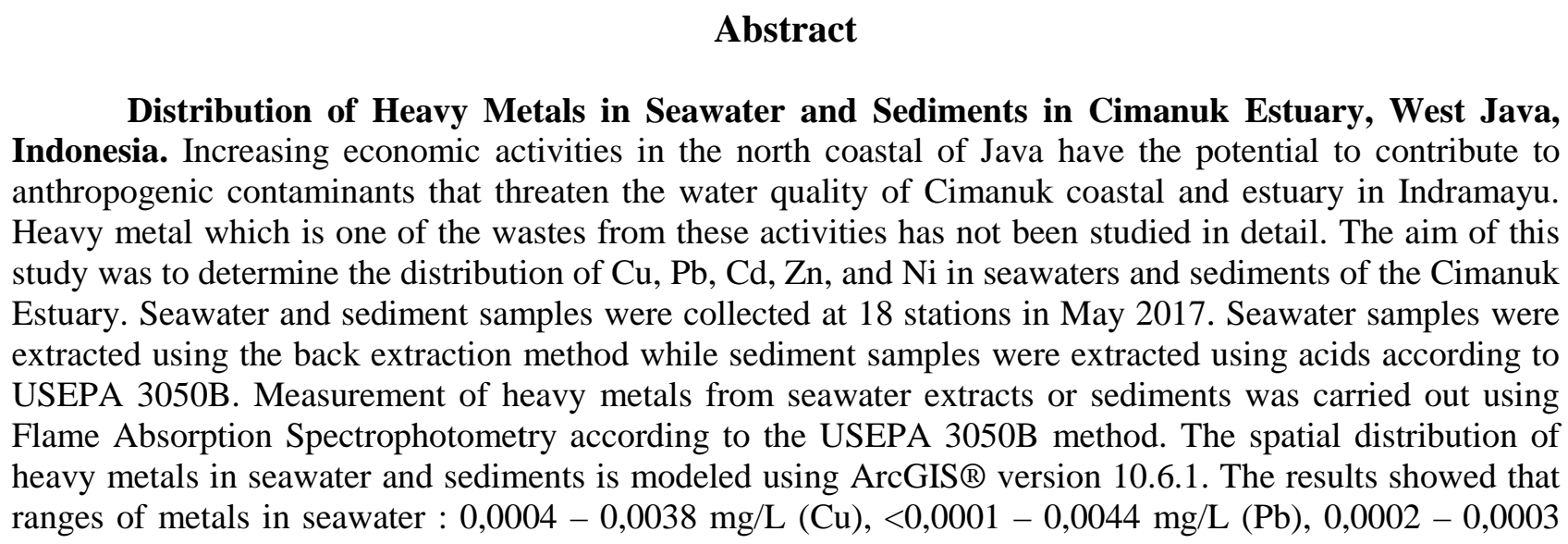


$\mathrm{mg} / \mathrm{L}(\mathrm{Cd}), 0,0005-0,0119 \mathrm{mg} / \mathrm{L}(\mathrm{Zn})$, and $0,0020-0,0052 \mathrm{mg} / \mathrm{L}(\mathrm{Ni})$. While the metal content in sediments are $12,36-54,08 \mathrm{mg} / \mathrm{kg}(\mathrm{Cu}), 6,43-15,72 \mathrm{mg} / \mathrm{kg}(\mathrm{Pb}), 0,07-0,37 \mathrm{mg} / \mathrm{kg}(\mathrm{Cd}), 64,53-85,16$ $\mathrm{mg} / \mathrm{kg}(\mathrm{Zn})$, and $19,66-62,85 \mathrm{mg} / \mathrm{kg}(\mathrm{Ni})$. Spatial distribution models show that heavy metals in seawater and sediments show identical patterns. High level of metals are generally detected at the stations located closed to the mainland, indicating that heavy metals are enrichment from terrestrial anthropogenic activities.

Keywords: heavy metal, anthropogenic activities, Cimanuk, seawater, sediment.

\section{Pendahuluan}

Pencemaran lingkungan terjadi jika adanya polutan yang melewati batas toleransi dan menyebabkan kerusakan pada makhluk hidup (Mohammed et al., 2011). Salah satu bahan pencemar yang berbahaya adalah logam berat. Keberadaan logam berat memberikan efek ekologi negatif pada lingkungan karena tidak dapat terdegradasi, mengalami bioakumulasi (Saher \& Siddiqui, 2019) dan biomagnifikasi (Vandecasteele et al., 2004) serta bersifat toksik ketika melewati batas tertentu (Rosado et al., 2016) sehingga berdampak buruk pada lingkungan dan kehidupan.

Logam berat yang terdapat di perairan berasal dari sumber alami berupa pelapukan bebatuan dan aktivitas vulkanik (Peng et al., 2018). Selain itu, logam berat masuk ke perairan melalui sumber antropogenik yang terkait dengan aktivitas manusia seperti pelayaran, pertambangan, pertanian, industrialisasi, urbanisasi, limpasan air hujan, dan limbah perkotaan (Duodu et al., 2017; Ismail et al., 2016; Ke et al., 2017; $\mathrm{Vu}$ et al., 2017). Sumber antropogenik yang masuk ke lingkungan akuatik terakumulasi di sedimen melalui proses adsorpsi, presipitasi, copresipitasi, dan efek biologi (Peng et al., 2018) sehingga konsentrasi logam berat di sedimen jauh lebih besar dibandingkan di badan air. Ketika terjadi perubahan lingkungan secara fisikokimia, logam berat yang terakumulasi di sedimen akan terlarut ke badan air dan masuk ke rantai makanan (Peng et al., 2009) sehingga menimbulkan kerugian lingkungan dan keterpaparan biota terhadap logam berat semakin meningkat ( $\mathrm{Fu}$ et al., 2013).

Perairan Cimanuk merupakan bagian pesisir laut Jawa yang terletak di Kabupaten Indramayu. Perairan ini merupakan muara dari sungai Cimanuk yang berhulu di kaki Gunung Papandayan di Kabupaten Garut. Daerah aliran Sungai Cimanuk dengan panjang $\pm 180 \mathrm{~km}$ sebagian besar digunakan untuk keperluan pertanian $(66 \%)$ yang meliputi persawahan, perkebunan dan ladang, hutan (29\%), dan sisanya berupa pemukiman, perikanan, kawasan perdagangan, dan industri (Gitarama et al., 2016;
Kepmen PU, 2010; Sutriati, 2011), sedangkan hilir bagian timur terdapat pelabuhan dan industri perkapalan (Setyawan, 2017) karena memiliki aliran sungai yang cukup lebar. Jumlah penduduk semakin meningkat sehingga pemukiman penduduk terus berekspansi dari kawasan lahan kering ke arah lahan basah mengikuti alur-alur sungai (Setyawan, 2017). Pertumbuhan penduduk dan aktivitas masyarakat yang tinggi berdampak pada peningkatan pencemaran logam berat sepanjang sungai dan muara sungai.

Tampubolon et al. (2018) melaporkan bahwa Muara Sungai Cimanuk memiliki keragaman iktiofauna yang terdiri atas 103 spesies ikan dari 41 famili dan 14 ordo. Ikan ikan tersebut menghuni seluruh kolom perairan di muara sungai. Sementara itu, Muara Sungai Cimanuk merupakan ekosistem dengan tipe perairan semi tertutup (Aditriawan \& Rahardjo, 2016) sehingga rentan terhadap penumpukan bahan pencemaran, baik yang berasal dari kegiatan pertanian dan perindustrian maupun yang berasal dari limbah rumah tangga. Logam berat $\mathrm{Cu}, \mathrm{Pb}, \mathrm{Cd}, \mathrm{Zn}$, and $\mathrm{Ni}$ merupakan logam yang sering dipergunakan oleh manusia. Logam $\mathrm{Pb}$ dan $\mathrm{Cd}$ merupakan logam yang terdapat dalam bahan bakar fosil. Selain itu, logam $\mathrm{Pb}$ dan $\mathrm{Cd}$ termaktub dalam daftar unsur beracun berdasar Agency for Toxic Substances and Disease Registry (ATSDR, 2019; 2012). Kedua logam ini memiliki tingkat toksisitas yang tinggi terhadap makhluk hidup. Sementara itu, Logam $\mathrm{Cu}, \mathrm{Zn}$, dan Ni merupakan logam yang yang banyak digunakan dalam bermacam perabot manusia sebagai pelapis perkakas ataupun bahan baku perabot (Li \& Ren, 2011). Sehingga perubahan kelima logam tersebut di perairan disinyalir berhubungan dengan aktifitas manusia. Penelitian ini bertujuan untuk menentukan konsentrasi $\mathrm{Cu}, \mathrm{Pb}, \mathrm{Cd}, \mathrm{Zn}$, dan $\mathrm{Ni}$ yang terlarut dalam air laut dan dalam sedimen serta melakukan penilaian kondisi perairan berdasarkan konsentrasi logam berat tersebut.

\section{Metodologi}

\section{Lokasi Sampling}

Pengambilan sampel air laut dan sedimen dilakukan pada Bulan Mei 2017 di Perairan 
Cimanuk, Indramayu, Jawa Barat. Bulan Mei dipilih sebagai musim peralihan dari musim hujan ke kemarau sehingg intensitas hujan lebat telah berkurang. Akan tetapi limpasan dari daratan selama musim penghujan masih berpengaruh ke estuari. Sampel di ambil dari 18 stasiun dengan posisi geografis antara $6^{\circ} 12^{\prime} 22,62^{\prime \prime} \mathrm{LS}$ $6^{\circ} 18 ' 24,73$ "LS dan $108^{\circ} 9^{\prime} 11,79^{\prime \prime B T} \quad-$ $108^{\circ} 23^{\prime} 38,38^{\prime \prime B T}$ seperti yang ditunjukkan oleh Gambar 1. Sedangkan kondisi fisikokimia Perairan Cimanuk (salinitas dan suhu) di ukur menggunakan water quality checker SCT (Salinity, Conductivity, and Temperature) YSI.

\section{Tahap Pengambilan Sampel di Lapangan}

Pengambilan sampel air laut dilakukan dengan menggunakan van dorn sampler dengan posisi kurang lebih satu meter dari permukaan. Sebanyak satu liter sampel air laut di saring menggunakan kertas saring sellulosa nitrat dengan pori-pori $0,45 \mu \mathrm{m}$ dan dimasukkan ke dalam botol polietilen. Sampel air laut diawetkan dengan $\mathrm{HNO}_{3}$ pekat hingga $\mathrm{pH}<2$ dan di simpan dalam cool box (Batley \& Gardner, 1977).

Pengambilan sampel sedimen dilakukan dengan menggunakan box core grab stainless steel pada lapisan permukaan $(0-10 \mathrm{~cm})$ dan dilakukan satu kali pada tiap stasiun. Sampel sedimen dimasukkan ke dalam wadah plastik polietilen (PE) dan di simpan dalam cool box untuk menghindari oksidasi dari logam besi (Loring \& Rantala, 1992). Penyimpanan dilakukan pada suhu $\pm 4^{\circ} \mathrm{C}$.

\section{Analisis Logam Berat dalam Air Laut}

Di laboratorium, sebanyak $250 \mathrm{~mL}$ sampel air laut diekstraksi dengan menggunakan bahan pengompleks APDC dan MIBK. Proses ekstraksi dilakukan menggunakan corong pemisah (separation funnel) berbahan Teflon. Fasa organik yang diperoleh diekstraksi kembali ke fase air dengan $\mathrm{HNO}_{3}$ pekat (Hutagalung et al., 1997; Lestari et al., 2010; Magnusson \& Westerlund, 1981). Konsentrasi logam berat $\mathrm{Cu}, \mathrm{Pb}, \mathrm{Cd}, \mathrm{Zn}$, dan Ni yang terlarut dalam sampel air laut di ukur dengan menggunakan Flame AAS SpectrAA-20 Plus Varian dengan nyala campuran udaraasetilen. Hasil pengukuran logam berat dalam air laut di analisis dengan membandingkan konsentrasi logam berat yang diperoleh terhadap Baku Mutu Air laut KMNKLH No : 51. Tahun 2004 yang ditetapkan oleh Kantor Menteri Negara Kependudukan dan Lingkungan Hidup (KMNKLH) untuk kepentingan kehidupan biota laut dan di beberapa daerah lainnya. Nilai Ambang Batas Baku Mutu Air Laut untuk peruntukan kehidupan biota laut yakni $\mathrm{Cu}=0,008$ $\mathrm{mg} / \mathrm{L}, \mathrm{Pb}=0,008 \mathrm{mg} / \mathrm{L}, \mathrm{Cd}=0,001 \mathrm{mg} / \mathrm{L}, \mathrm{Zn}=$ $0,05 \mathrm{mg} / \mathrm{L}$, dan $\mathrm{Ni}=0,05 \mathrm{mg} / \mathrm{L}$.

\section{Analisis Logam Berat dalam Sedimen}

Di laboratorium, sampel sedimen dikeringkan dalam oven pada suhu $105^{\circ} \mathrm{C}$ selama 24 jam kemudian dihaluskan (Hutagalung et al., 1997). Satu gram sampel sedimen kering didestruksi dengan campuran larutan $\mathrm{HNO}_{3}-\mathrm{H}_{2} \mathrm{O}_{2}-$ $\mathrm{HCl}$ pada suhu $95^{\circ} \mathrm{C}$ selama 6 jam (USEPA, 1996). Konsentrasi logam berat $\mathrm{Cu}, \mathrm{Pb}, \mathrm{Cd}, \mathrm{Zn}$, $\mathrm{Ni}$, dan Fe dalam sampel sedimen di ukur dengan menggunakan Flame AAS SpectrAA-20 Plus Varian dengan nyala campuran udara-asetilen. Pengukuran terhadap bahan yang bersertifikat, CRM PACS-2 dari Institude for National Measurement Standards, National Research Council of Canada, dilakukan untuk menjamin mutu pengukuran. Hasil analisis data CRM untuk $\mathrm{Cu}, \mathrm{Pb}, \mathrm{Cd}, \mathrm{Zn}, \mathrm{Ni}$, dan $\mathrm{Fe}$ menunjukkan nilai yang bagus dengan range recovery $94,8 \%-99,8 \%$ sepeti pada Tabel 1. Analisis konsentrasi logam berat dalam sedimen dibandingkan dengan pedoman mutu sedimen, antara lain dengan ANZECC/ARMCANZ (2000) dari Australia dan Selandia Baru dan CCME (2001) dari Canada karena Indonesia belum memiliki pedoman mutu untuk sedimen.

Dalam guideline dari ANZECC/ ARMCANZ terdapat nilai ISQG-low dan ISQGhigh. Nilai ISQG-low sebagai efek toksisitas yang rendah namun perlu perhatian lanjut, sedangkan nilai ISQG-high sebagai acuan untuk evaluasi efek buruk yang diperkirakan terjadi pada setengah populasi yang terpapar. Di atas nilai ISQG-high ditafsirkan menyebabkan efek buruk yang signifikan pada organisme akuatik. Dalam guideline CCME terdapat nilai Interim Sediment Quality Guidline (ISQG) dan Probable Effect Level (PEL). Nilai ISQG digunakan sebagai batas potensi pengaruh negatif terhadap biota, sedangkan nilai PEL digunakan untuk evaluasi efek biologis yang berdampak merugikan untuk organisme.

\section{Penilaian Enrichment Factor (EF) untuk sedimen}

Salah satu metode yang digunakan untuk assesment kualitas sedimen adalah penilaian yang didasarkan pada Enrichment Factor (EF) atau Enrichment Ratio (ER) yang diformulasikan sebagai berikut (Sutherland, 2000):

$$
E F=\frac{\frac{C_{n}}{C_{r}} \text { sampel }}{\frac{C_{n}}{C_{r}} \text { background }}
$$

Keterangan:

$\mathrm{C}_{\mathrm{n}}$ sampel = konsentrasi logam dalam sampel, $C_{r}$ sampel $=$ konsentrasi logam rujukan 
dalam sampel, $\mathrm{C}_{\mathrm{n}}$ background dan $\mathrm{C}_{\mathrm{r}}$ background = konsentrasi logam dan logam rujukan dalam sedimen yang masih alami, dengan menggunakan nilai rata-rata logam dalam kerak bumi.

Metode ini digunakan untuk mengetahui kelimpahan logam berat di sedimen. Logam Fe digunakan sebagai logam rujukan dalam penilaian Enrichment Factor karena Fe tidak terkait dengan logam lain, memiliki sifat geokimia yang mirip dengan logam runutan serta memiliki konsentrasi alami yang tinggi dan cenderung seragam (Taylor, 1964; Varol, 2011). Kriteria nilai EF mengacu pada Sutherland (2000), dimana nilai EF $<2$ mengindikasikan pengkayaan minimal; EF 2 - 5 mengindikasikan pengayaan sedang (moderate);
EF 5 - 20 mengindikasikan pengayaan cukup (significant); EF 20 - 40 mengindikasikan pengayaan tinggi (very high); dan $\mathrm{EF}>40$ mengindikasikan pengayaan sangat tinggi (extremely high).

\section{Analisis Data}

Pengujian statistik dengan Korelasi Pearson digunakan untuk memahami hubungan logam dengan parameter fisik di air laut dan memahami hubungan antar logam di sedimen. Sedangkan distribusi spasial masing-masing logam berat disajikan dalam bentuk peta menggunakan software ArcGIS 10.6.1.

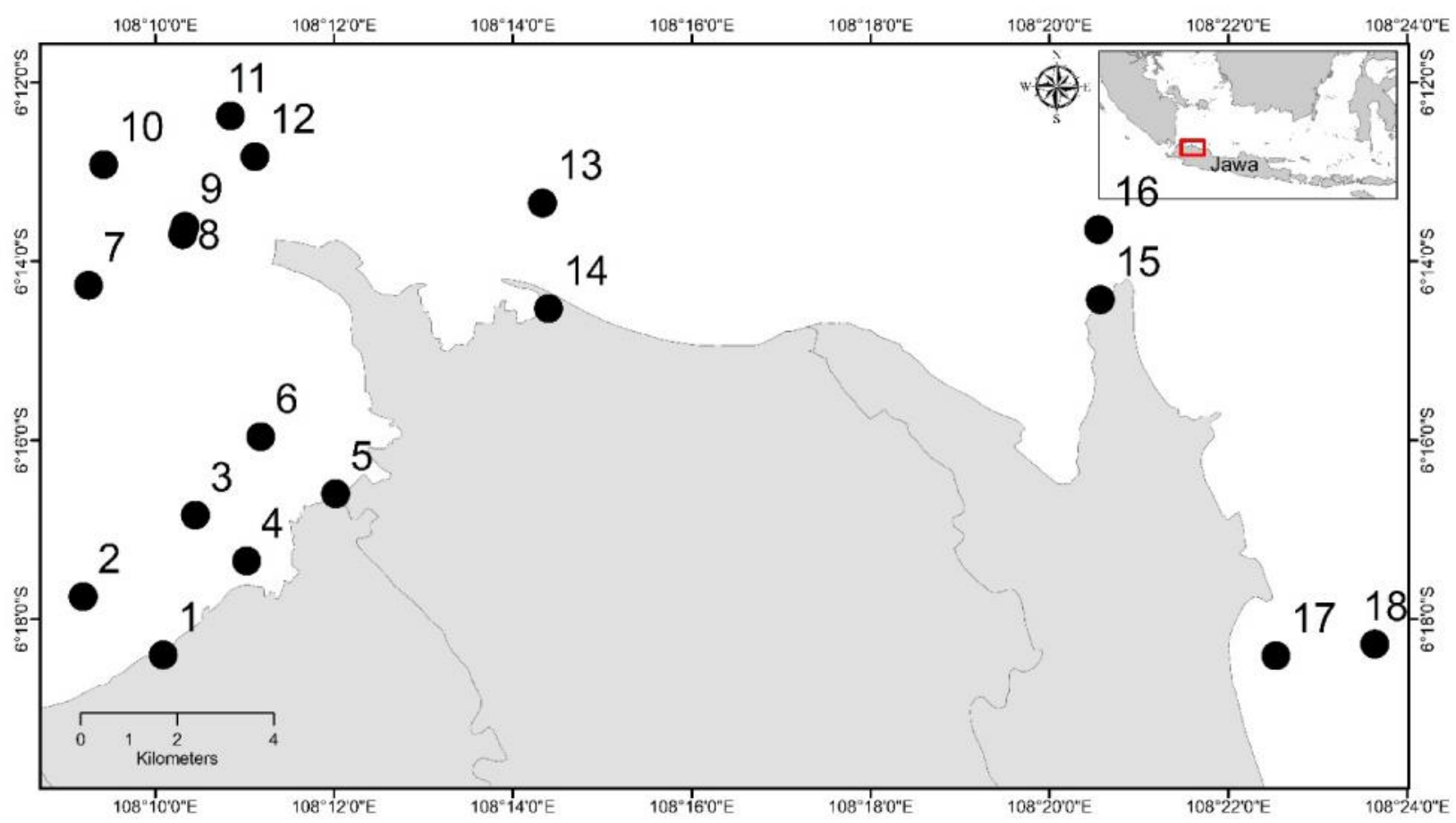

Gambar 1. Lokasi pengambilan sampel di Perairan Cimanuk, Jawa Barat

Figure 1. Sampling location in Cimanuk Estuary, West Java

Tabel 1. Jaminan mutu pengukuran dengan menggunakan CRM PACS-2

Table 1. Quality assurance measurement using CRM PACS-2

\begin{tabular}{|c|c|c|c|}
\hline Element & $\begin{array}{c}\text { Founded CRM PACS-2 value } \\
(\mathrm{mg} / \mathrm{Kg} \text { DW })\end{array}$ & $\begin{array}{c}\text { Certified CRM PACS-2 value } \\
(\mathrm{mg} / \mathrm{Kg} \text { DW) }\end{array}$ & Recovery (\%) \\
\hline $\mathrm{Cu}$ & 309 & $310 \pm 12$ & 99.7 \\
\hline $\mathrm{Pb}$ & 179 & $183 \pm 8$ & 97.8 \\
\hline $\mathrm{Cd}$ & 2 & $2.11 \pm 0.15$ & 94.8 \\
\hline $\mathrm{Zn}$ & 363 & $364 \pm 23$ & 99.7 \\
\hline $\mathrm{Ni}$ & 39 & 39.5 & 98.7 \\
\hline $\mathrm{Fe}$ & 40798 & 40900 & 99.8 \\
\hline
\end{tabular}


Hasil

\section{Kondisi Perairan Cimanuk}

Salinitas, suhu dan kedalaman di ukur untuk mengetahui kondisi fisika kimia perairan Cimanuk seperti pada Tabel 2. Salinitas air laut di stasiun 8 dan 9 terukur 17 psu sedangkan stasiun lain memiliki salinitas air laut berkisar antara 28,3 - 31,7 psu. Suhu air laut ketika pengamatan dilakukan berkisar antara $29,1-31,9^{\circ} \mathrm{C}$. Kedalaman pengambilan sampel sedimen dari permukaan air laut bervariasi antara $0,5 \mathrm{~m}-2 \mathrm{~m}$ untuk stasiun yang dekat dengan daratan dan antara $2 \mathrm{~m}-12 \mathrm{~m}$ untuk stasiun yang lebih jauh dari daratan.

\section{Konsentrasi Logam Berat dalam Air Laut}

Hasil penelitian pada Tabel 3 menunjukkan konsentrasi $\mathrm{Cd}$ dalam air laut memiliki nilai yang homogen, sedangkan logam $\mathrm{Cu}, \mathrm{Pb}, \mathrm{Zn}$, dan $\mathrm{Ni}$ menunjukkan nilai yang bervariasi. Logam nikel terdeteksi melewati Nilai Ambang Batas (NAB) untuk kehidupan biota laut yang ditetapkan oleh KMNKLH No 51 Tahun 2004, sedangkan logam lain masih di bawah NAB. Berdasarkan batas nilai alami konsentrasi logam di air laut dalam Waldichuck (1974), semua logam telah melewati nilai alamiah hampir di semua stasiun dan diindikasikan telah mengalami pengayaan di air laut.

Tabel 4 menunjukkan Korelasi Pearson yang digunakan untuk melihat pengaruh salinitas air laut terhadap logam terlarut. Logam terlarut $\mathrm{Cu}$ dan $\mathrm{Pb}$ memiliki korelasi negatif terhadap salinitas, $\mathrm{Cd}$ dan Ni. Sedangkan $\mathrm{Cu}$ dan $\mathrm{Zn}$ memiliki korelasi dengan $\mathrm{p}<0,05$.

\section{Konsentrasi Logam Berat dalam Sedimen}

Konsentrasi logam berat dalam sedimen disajikan pada Tabel 5. Hasil yang diperoleh dibandingkan dengan pedoman mutu sedimen, seperti ANZECC/ARMCANZ (2000) dari Australia dan Selandia Baru dan CCME (2001) dari Canada. Kadar logam timbal, kadmium, dan zink yang terdeteksi di semua stasiun masih berada jauh di bawah ambang batas yang ditetapkan oleh ANZECC/ARMCANZ guideline ataupun CCME. Kadar tembaga di semua stasiun masih berada di bawah ambang batas yang ditetapkan oleh ANZECC/ARMCANZ guideline, namun sebagian besar berada di atas nilai ISQG (Interim Sediment Quality Guidline) yang ditetapkan oleh CCME. Hampir semua stasiun memiliki kadar nikel yang melewati batas nilai $I S Q G$ low, bahkan ada yang diatas nilai $I S Q G$ high yang ditetapkan oleh ANZECC/ARMCANZ guideline.

Koefisien korelasi Pearson antar logam $\mathrm{Cu}, \mathrm{Pb}, \mathrm{Cd}, \mathrm{Zn}$, dan $\mathrm{Ni}$ di sedimen disajikan dalam tabel 6. Pasangan $\mathrm{Ni}-\mathrm{Cu}$ dan $\mathrm{Ni}-\mathrm{Zn}$ menunjukkan korelasi yang signifikan dengan $\mathrm{P}<$ 0.01 , dan $\mathrm{Zn}-\mathrm{Cu}$ menunjukkan korelasi yang signifikan dengan $\mathrm{P}<0,05$. Sedangkan $\mathrm{Pb}$ dan $\mathrm{Cd}$ tidak menunjukkan korelasi dengan logam lainnya.

Distribusi logam berat tembaga $(\mathrm{Cu})$, timbal $(\mathrm{Pb})$, kadmium $(\mathrm{Cd})$, zink $(\mathrm{Zn})$, dan nikel (Ni) yang terlarut di air laut dan di sedimen ditampilkan pada Gambar 2. Konsentrasi logam cenderung terukur lebih tinggi untuk stasiun yang berada dekat dengan daratan, baik di air laut maupun di sedimen.

Gambar 3 menampilkan faktor pengayaan (enrichment factor) logam berat di sedimen. Beberapa stasiun menunjukkan nilai $\mathrm{EF}>1$. Pengayaan logam $\mathrm{Cd}$ terdeteksi tinggi di stasiun $1,3,7,9,10$, dan 18; logam $\mathrm{Pb}$ di stasiun $1,3,5$, 6 , dan 7; sedangkan logam lain cenderung sama di semua stasiun. 
Tabel 2. Kondisi Fisikokimia Perairan Cimanuk (salinitas, suhu, dan kedalaman)

Table 2. Physicochemical condition of Cimanuk Estuary (salinity, temperature, and depth)

\begin{tabular}{|c|c|c|c|}
\hline Station & Salinity (psu) & Temperature $\left.\mathbf{(}^{\mathbf{0}} \mathbf{C}\right)$ & Depth $(\mathbf{m})$ \\
\hline 1 & 31.2 & 31.9 & 0.5 \\
\hline 2 & 31.1 & 30.0 & 3.0 \\
\hline 3 & 31.0 & 30.0 & 3.0 \\
\hline 4 & 28.3 & 31.3 & 0.5 \\
\hline 5 & 29.5 & 31.6 & 0.5 \\
\hline 6 & 31.0 & 29.9 & 2.0 \\
\hline 7 & 31.7 & 29.8 & 8.0 \\
\hline 8 & 17.0 & 31.8 & 0.5 \\
\hline 9 & 17.0 & 31.8 & 1.0 \\
\hline 10 & 30.3 & 29.1 & 12.0 \\
\hline 11 & 31.1 & 30.4 & 12.0 \\
\hline 12 & 31.4 & 30.1 & 2.0 \\
\hline 13 & 31.7 & 30.4 & 10.0 \\
\hline 14 & 31.5 & 30.5 & 2.0 \\
\hline 15 & 31.1 & 29.6 & 2.0 \\
\hline 16 & 31.3 & 30.2 & 7.0 \\
\hline 17 & 29.8 & 29.6 & 3.0 \\
\hline 18 & 30.1 & 29.9 & 7.0 \\
\hline
\end{tabular}

Tabel 3. Konsentrasi logam berat dalam air laut Perairan Cimanuk

Table 3. Heavy metals concentration in seawater of Cimanuk Estuary

\begin{tabular}{|l|l|l|l|l|l|}
\hline \multirow{2}{*}{} & \multicolumn{5}{|c|}{ Heavy metals concentration in seawater(mg/L) } \\
\cline { 2 - 6 } & $\mathrm{Cu}$ & $\mathrm{Pb}$ & $\mathrm{Cd}$ & $\mathrm{Zn}$ & $\mathrm{Ni}$ \\
\hline Min & 0.0004 & $\mathrm{Nd}$ & 0.0002 & 0.0005 & 0.0020 \\
\hline Max & 0.0038 & 0.0044 & 0.0003 & 0.0119 & 0.0052 \\
\hline Average & 0.00124 & 0.00276 & 0.00024 & 0.00265 & 0.00341 \\
\hline Treshhold (NAB) $^{1}$ & 0.0080 & 0.0080 & 0.0010 & 0.0500 & 0.0500 \\
\hline Natural value $^{2}$ & 0.0020 & 0.00003 & 0.00011 & 0.0020 & 0.0020 \\
\hline
\end{tabular}

Nd: not detected

${ }^{1}$ Nilai ambang batas (NAB), KMNKLH (2004)

${ }^{2}$ Waldichuck (1974)

Tabel 4. Koefisien korelasi Pearson untuk salinitas dan logan terlarut $(\mathrm{n}=18)$

Table 4. Perason Correlation coefficient for salinity and dissolved metals $(\mathrm{n}=18)$

\begin{tabular}{|l|c|l|l|l|l|l|}
\hline & Salinity & $\mathbf{C u}$ & $\mathbf{C d}$ & $\mathbf{Z n}$ & $\mathbf{N i}$ & $\mathbf{P b}$ \\
\hline Salinity & 1.000 & & & & & \\
\hline $\mathbf{C u}$ & -0.049 & 1.000 & & & & \\
\hline $\mathbf{C d}$ & 0.158 & -0.235 & 1.000 & & & \\
\hline $\mathbf{Z n}$ & 0.091 & $\mathbf{0 . 5 0 4}$ & -0.313 & 1.000 & & \\
\hline $\mathbf{N i}$ & 0.038 & -0.099 & 0.040 & 0.363 & 1.000 & \\
\hline $\mathbf{P b}$ & -0.145 & -0.336 & 0.450 & -0.625 & 0.015 & 1.000 \\
\hline
\end{tabular}


Oseanologi dan Limnologi di Indonesia 2020 5(1): 19-32

Tabel 5. Konsentrasi logam berat dalam sedimen Perairan Cimanuk

Table 5. Heavy metals concentration in sediments of Cimanuk Estuary

\begin{tabular}{|l|l|c|c|c|c|c|}
\hline \multirow{2}{*}{} & \multicolumn{5}{|c|}{$\begin{array}{c}\text { Heavy metals concentration in sediments } \\
\text { (mg/kg dry weight) }\end{array}$} \\
\cline { 3 - 7 } & & $\mathrm{Cu}$ & $\mathrm{Pb}$ & $\mathrm{Cd}$ & $\mathrm{Zn}$ & $\mathrm{Ni}$ \\
\cline { 2 - 7 } & Min & 12.36 & 6.43 & 0.07 & 64.53 & 19.66 \\
\cline { 2 - 7 } & Max & 54.08 & 15.72 & 0.37 & 85.16 & 62.85 \\
\cline { 2 - 7 } & Average & 28.75 & 12.24 & 0.17 & 74.32 & 31.17 \\
\hline \multirow{3}{*}{$\begin{array}{l}\text { ANZECC/ARMCANZ } \\
\text { Guidelines }\end{array}$} & Low & 65 & 50 & 1.5 & 200 & 21 \\
\cline { 2 - 7 } & High & 270 & 220 & 10 & 410 & 52 \\
\hline \multirow{2}{*}{ CCME } & ISQG $^{1}$ & 18.7 & 30.2 & 0.7 & 124 & - \\
\cline { 2 - 7 } & PEL $^{2}$ & 108 & 112 & 4.2 & 271 & - \\
\hline
\end{tabular}

${ }^{1}$ ISQG, interim sediment quality guidelines

${ }^{2} \mathrm{PEL}$, probable effect levels

Tabel 6. Koefisien korelasi Pearson logam berat dalam sedimen $(\mathrm{n}=18)$

Table 6. Pearson correlation coefficient between heavy metals in sediment samples $(n=18)$

\begin{tabular}{|c|c|c|c|c|c|}
\hline & $\mathbf{C u}$ & $\mathbf{P b}$ & $\mathbf{C d}$ & $\mathbf{Z n}$ & $\mathbf{N i}$ \\
\hline $\mathbf{C u}$ & 1.000 & & & & \\
\hline $\mathbf{P b}$ & 0.160 & 1.000 & & & \\
\hline $\mathbf{C d}$ & 0.135 & -0.140 & 1.000 & & \\
\hline $\mathbf{Z n}$ & $\mathbf{0 . 5 3 1} *$ & 0.023 & -0.200 & 1.000 & \\
\hline $\mathbf{N i}$ & $\mathbf{0 . 7 5 9} * *$ & 0.134 & -0.165 & $\mathbf{0 . 7 2 5} * *$ & 1.000 \\
\hline
\end{tabular}

$* \mathrm{p}<0.05(\mathbf{t} \mathbf{0 . 0 2 5})$

$* * p<0.01$ (t 0.005) 
Harmesa, Lestari \& Budiyanto
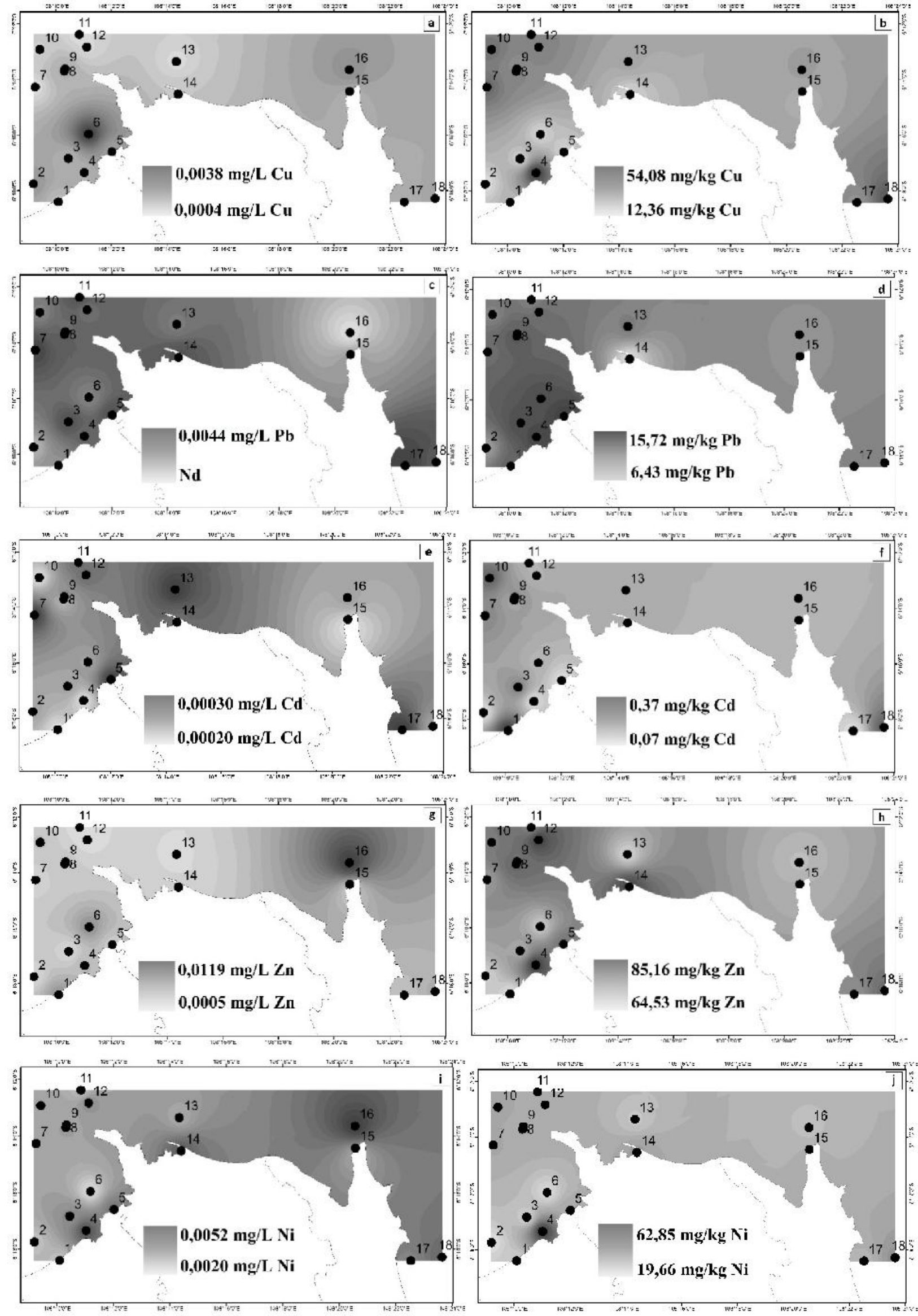

Gambar 2. Distribusi logam berat di air laut, (a) Tembaga; (c) Timbal; (e) Kadmium; (g) Zink; (i) Nikel;

Distribusi logam berat di sedimen, (b) Tembaga; (d) Timbal; (f) Kadmium; (h) Zink; (j) Nikel

Figure 2. Heavy metals distribution in seawater (a) copper; (c) lead; (e) cadmium; (g) zinc; (i) nickel; Heavy metals distribution in sediment (b) copper; (d) lead; (f) cadmium; (h) zinc; (j) nickel 


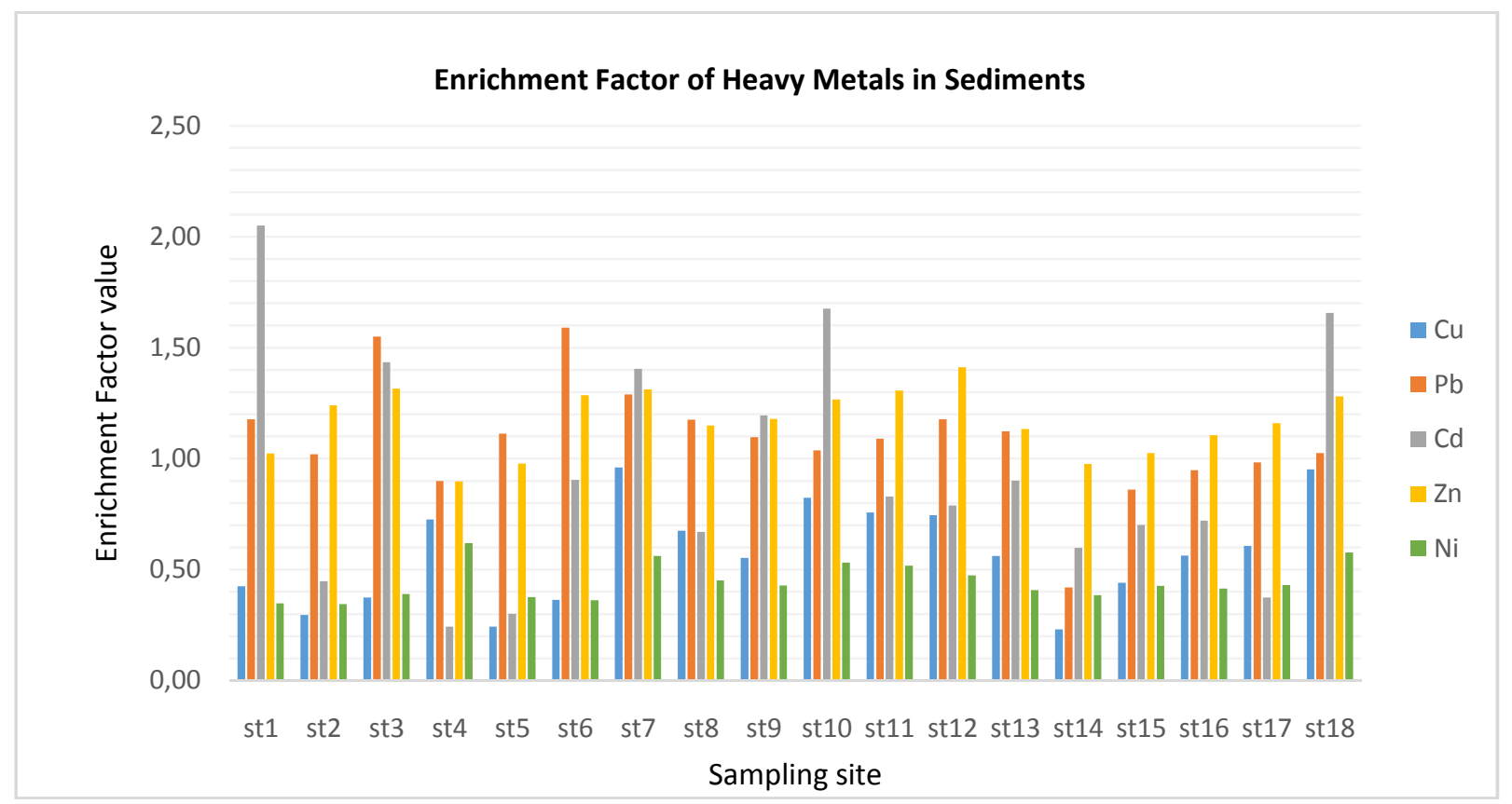

Gambar 3. Faktor pengayaan (EF) logam berat di lokasi sampling, Perairan Cimanuk Figure 3. Enrichment Factor (EF) of heavy metals by sampling site, Cimanuk Estuary

\section{Pembahasan}

Daerah pengambilan sampel terdiri dari 18 stasiun yang tersebar di berbagai muara dan berasal dari aliran Sungai Cimanuk yang melewati beberapa wilayah di Jawa Barat. Stasiun 1, 4, 5, 8, $9,12,14,15,17$, merupakan muara dari sungai Cimanuk yang memiliki kedalaman yang berkisar antara $0,5 \mathrm{~m}-2 \mathrm{~m}$. Stasiun 2, 3, 6, 7, 10, 11, 13, 16,18 merupakan daerah perairan yang lebih jauh dari daratan dengan kedalaman berkisar antara 2 m - $12 \mathrm{~m}$. Sedangkan stasiun 17 dan 18 berada di wilayah Karangsong yang memiliki aliran sungai yang lebih lebar sehingga dapat dilalui oleh kapal. Alur kanal Karangsong digunakan sebagai pelabuhan dan industri perkapalan, sedangkan tepi pantai Karangsong digunakan sebagai wisata pantai pasir (Setyawan, 2017).

Temperatur air di bawah permukaan yang terukur berkisar antara $29,1^{\circ} \mathrm{C}-31,9^{\circ} \mathrm{C}$ menunjukkan karakteristik daerah perairan tropis (Abowei, 2009) dan cocok untuk habitat ikan (Mulyanto sebagaimana dikutip dalam Eddiwan, 2018) yang terdiri atas 103 jenis ikan dari 41 famili dan 14 ordo (Tampubolon et al., 2018) yang menghuni seluruh kolom air di perairan muara sungai Cimanuk. Nilai salinitas permukaan perairan Indonesia berkisar antara $32-34$ psu (Eddiwan, 2018), sedangkan salinitas yang terukur di Perairan Muara Cimanuk berkisar antara $17-31,7$ psu. Penurunan salinitas perairan ini disebabkan adanya proses presipitasi dan masukan air tawar dari sungai Cimanuk.
Penyebaran logam berat $\mathrm{Pb}, \mathrm{Cu}, \mathrm{Cd}, \mathrm{Zn}$, dan Ni tidak merata di titik sampling perairan Cimanuk. Distribusi logam di perairan dipengaruhi oleh beberapa faktor seperti sumber logam, kecepatan air, salinitas air, $\mathrm{pH}$, dan kondisi hidrodinamik (Liu et al., 2016b). Sumber logam berat cenderung berasal dari aktivitas masyarakat sepanjang aliran sungai Cimanuk dan kegiatan di sekitar titik sampling. Daerah aliran Sungai Cimanuk banyak digunakan untuk keperluan pertanian (persawahan, perkebunan, dan ladang), pemukiman, perikanan, kawasan perdagangan dan industri (Gitarama et al., 2016; Sutriati, 2010). Limbah cair yang berasal dari aktivitas industri batik rumahan yang di buang langsung ke sungai disinyalir sebagai salah satu penyebab masuknya logam berat ke muara Cimanuk (Gitarama et al., 2016). Limbah industri batik mengandung beberapa logam berat, seperti kromium $(\mathrm{Cr})$, besi $(\mathrm{Fe})$, tembaga $(\mathrm{Cu})$, seng $(\mathrm{Zn})$, kadmium $\mathrm{Cd})$, timbal $(\mathrm{Pb})$, nikel $(\mathrm{Ni})$, dan mangan $(\mathrm{Mn})$ (Natalina \& Firdaus, 2017; Riwayati et al., 2014). Sumber logam lain diperkirakan berasal dari kegiatan perikanan tambak di sepanjang tepi pantai dan industri perkapalan di alur kanal Karangsong (Setyawan, 2017). Pakan yang digunakan dalam kegiatan perikanan tambak mengandung logam esensial seperti $\mathrm{Cu}, \mathrm{Zn}$, dan $\mathrm{Cr}$ serta logam lain seperti $\mathrm{Pb}$ dan $\mathrm{Cd}$ (Adeniji \& Okedeyi, 2017).

Logam dengan konsentrasi tinggi umumnya terdeteksi di stasiun depan muara Sungai Cimanuk dan stasiun yang berlokasi dekat 
dengan daratan. Hal ini mengindikasikan sumber kontaminan logam berasal dari daratan yang dibawa oleh air sungai. Secara alamiah, logam berat sudah ada di dalam air laut sebagai komponen alami kerak bumi (Kumar at al., 2013) namun dalam konsentrasi yang sangat kecil (Hutagalung, 1997). Konsentrasi Ni, Cd, dan $\mathrm{Pb}$ dalam air laut di perairan Cimanuk terdeteksi telah melewati batas konsentrasi alami di semua stasiun sehingga dianggap telah mengalami pengayaan (Waldichuck, 1974), sedangkan $\mathrm{Cu}$ dan $\mathrm{Zn}$ terdeteksi melewati konsentrasi alami di beberapa stasiun. Konsentrasi $\mathrm{Cu}, \mathrm{Cd}, \mathrm{Pb}$, dan $\mathrm{Zn}$ dalam air laut masih berada di bawah baku mutu yang ditetapkan oleh KMNKLH Tahun 2004. Sedangkan konsentrasi Ni di stasiun 16 terdeteksi telah melewati Nilai Ambang Batas sehingga berpotensi memberikan dampak buruk pada biota.

Konsentrasi logam berat yang terdeteksi di sedimen jauh lebih tinggi dibandingkan di badan air, hal ini menunjukkan bahwa adanya proses akumulasi logam di sedimen. Hutagalung (1991) dan Baran et al. (2019) menyatakan bahwa logam berat mempunyai sifat yang mudah mengikat bahan organik, lalu mengendap di dasar perairan dan berikatan dengan partikel-partikel sedimen. Berdasarkan standar ANZECC/ ARMCANZ, konsentrasi $\mathrm{Zn}, \mathrm{Cd}$, dan $\mathrm{Pb}$ dalam sedimen masih berada di bawah nilai ISQG low namun di beberapa stasiun terdeteksi telah melewati kelimpahan rata-rata (Taylor, 1964). Hal ini didukung oleh nilai score Enrichment Factor (EF) dengan kisaran nilai 0,42 - 1,59 untuk logam timbal $(\mathrm{Pb}) ; 0,24-2,05$ untuk logam kadmium (Cd); dan 0,9 - 1,41 untuk logam zink (Zn). Nilai $\mathrm{EF}>1$ mengindikasikan terjadinya pengayaan logam di sedimen yang berasal dari sumber antropogenik (Brady et al., 2014). Sumber Pb, Cd, dan Zn kemungkinan berasal dari aktivitas dermaga, transportasi nelayan dan pembuatan kapal, bahan pengawet kayu, dan cat anti karat pada lambung kapal yang terjadi di sekitar perairan Cimanuk, serta masuknya pencemaran yang berasal dari aliran sungai Cimanuk dari kegiatan pertanian, penggunaan pestisida dan limbah buangan rumah tangga (Hutagalung, 1984; Sutherland, 2000).

Konsentrasi $\mathrm{Ni}$ telah melewati ambang batas yang ditetapkan oleh ANZECC/ARMCANZ guideline, baik batas nilai ISQG low maupun ISQG high. Hampir semua konsentrasi nikel berada di atas nilai $I S Q G$-low $(21 \mathrm{mg} / \mathrm{kg}$ berat kering), mengindikasikan bahwa logam nikel telah memberikan efek toksisitas yang rendah namun perlu perhatian lanjut. Konsentrasi nikel di stasiun 4 terdeteksi telah melewati nilai ISQGhigh (52 $\mathrm{mg} / \mathrm{kg}$ berat kering), mengindikasikan bahwa nikel yang terdapat di sedimen berpotensi memberikan dampak buruk yang signifikan pada organisme akuatik. Dalam konsentrasi yang tinggi, logam nikel memberikan dampak pada mikro organisme berupa gangguan membran sel, menghambat aktivitas enzim dan stress oksidatif (Ayangbenro \& Babalola, 2017; Macomber \& Hausinger, 2011). Logam nikel banyak digunakan dalam industry electroplating dan dalam pupuk fosfat (Carolin et al., 2017; Sutherland, 2000). Limbah rumah tangga dan kegiatan pertanian yang menggunakan pupuk fosfat di sepanjang daerah aliran sungai memiliki kontribusi dalam peningkatan logam nikel di sedimen.

Berdasarkan perbandingan dengan baku mutu sedimen dari CCME, konsentrasi $\mathrm{Pb}, \mathrm{Cd}$, dan Zn berada di bawah nilai PEL dan ISQG yang ditetapkan. Konsentrasi ogam $\mathrm{Cu}$ berada di bawah nilai PEL namun di atas nilai ISQG, yang berpotensi memberikan pengaruh negatif terhadap biota. Peningkatan konsentrasi tembaga dapat memberikan efek mengganggu fungsi sel dan menghambat aktivitas enzim (Ayangbenro \& Babalola, 2017) bagi mikroorganisme yang hidup di sekitar sedimen tersebut. Keberadaan $\mathrm{Cu}$ di perairan dapat diakibatkan oleh aktivitas vulkanik (Doelsch et al., 2005) dan aktivitas manusia. Sumber $\mathrm{Cu}$ yang berasal dari aktivitas manusia adalah aktivitas dermaga, transportasi nelayan dan pembuatan kapal, bahan pengawet kayu dan cat anti karat pada lambung kapal yang terjadi di sekitar perairan Cimanuk, serta masuknya pencemaran yang berasal dari aliran sungai Cimanuk dari kegiatan pertanian, pembuatan pestisida dan limbah buangan rumah tangga (Hutagalung, 1984; Sutherland, 2000).

$$
\text { Korelasi Pearson dari Tabel } 4
$$
menunjukkan bahwa tidak ada pengaruh salinitas terhadap logam terlarut di kolom air yang berada di muara Sungai Cimanuk. Pencampuran garam yang berasal dari air laut dan air tawar menyebabkan beberapa logam bermigrasi menjadi partikel (Tang et al., 2010). Koefisien korelasi Pearson antarlogam $\mathrm{Cu}, \mathrm{Pb}, \mathrm{Cd}, \mathrm{Zn}$, dan $\mathrm{Ni}$ di sedimen menunjukkan $\mathrm{Ni}-\mathrm{Cu}$ dan $\mathrm{Ni}-\mathrm{Zn}$ memiliki korelasi yang signifikan dengan $\mathrm{P}<$ 0,01. Sedangkan $\mathrm{Zn}-\mathrm{Cu}$ menunjukkan korelasi yang signifikan dengan $\mathrm{P}<0,05$ baik di air laut maupun di sedimen. Korelasi positif signifikan mengindikasikan bahwa logam berasosiasi satu sama lain, saling ketergantungan dan memiliki perilaku yang identik selama transportasi (Suresh et al., 2012), serta kemungkinan berasal dari sumber yang sama, baik sumber alami maupun sumber antropogenik (Liu et al., 2016). Korelasi $\mathrm{Ni}, \mathrm{Cu}$, dan $\mathrm{Zn}$ sangat mungkin berasal dari kegiatan perikanan tambak dan pertanian di 
sekitar delta Cimanuk dan sepanjang aliran sungai Cimanuk. Pengayaan ini dapat berasal dari pakan yang digunakan dalam pertambakan dan peternakan, juga peralatan pertanian yang mengandung zat anti karat, sebagai sumber dari logam Ni, Cu, dan Zn (Fuge, 2013).

Logam $\mathrm{Pb}$ dan $\mathrm{Cd}$ tidak menunjukkan korelasi dengan logam lainnya, baik di air laut maupun di sedimen. Menurut Rompas (sebagaimana dikutip dalam Rumahlatu, 2011), logam Cd di lingkungan perairan secara cepat di serap oleh organisme dalam bentuk ion bebas $\mathrm{Cd}^{2+}$. Ion $\mathrm{Cl}^{-}$yang berasal dari air laut berasosiasi dengan logam Cd membentuk senyawa kompleks yang sangat kuat (Budiyanto \& Lestari, 2013) seperti $\mathrm{CdCl}_{2}$ dan $\mathrm{CdCl}^{+}$. Sedangkan $\mathrm{Pb}$ cenderung terakumulasi di sedimen melalui proses kompleksitas dengan senyawa organik (Gupta et al., 2012).

Logam berat yang terdeteksi di sedimen perairan Cimanuk memiliki konsentrasi yang hampir sama dengan estuari Cisanggarung, Jawa Barat. Budiyanto dan Lestari (2014) melaporkan konsentrasi logam di sedimen estuari Cisanggarung bervariasi antara $0,52-0,73 \mathrm{mg} / \mathrm{kg}$ (Cd), 17,28 - 31,37 mg/kg (Cu), 7,01 - 23,94 $\mathrm{mg} / \mathrm{kg}(\mathrm{Pb})$, dan 65,23 - 142,52 mg/kg (Zn). Namun, konsentrasi logam berat di perairan Cimanuk relatif lebih rendah jika dibandingkan dengan konsentrasi logam berat di Teluk Jakarta yang berasal dari limbah kegiatan perkotaan dengan populasi masyarakat lebih tinggi. Konsentrasi logam berat di Teluk Jakarta menurut Budiyanto dan Lestari (2017) bervariasi antara $0,29-1,74 \mathrm{mg} / \mathrm{kg}(\mathrm{Cd}), 16,60-157 \mathrm{mg} / \mathrm{kg}(\mathrm{Cu})$, $15,90-75,8 \mathrm{mg} / \mathrm{kg}(\mathrm{Ni}), 7,80-89,4 \mathrm{mg} / \mathrm{kg}(\mathrm{Pb})$, dan $85,3-1270 \mathrm{mg} / \mathrm{kg}(\mathrm{Zn})$.

\section{Kesimpulan}

Hasil penelitian menunjukkan bahwa logam $\mathrm{Cu}, \mathrm{Pb}, \mathrm{Cd}, \mathrm{Zn}$, dan Ni di kolom air Perairan Cimanuk telah melewati batas alami di beberapa titik, namun hampir semuanya masih berada di bawah nilai ambang batas yang ditetapkan oleh KMNLHK. Logam dengan konsentrasi tinggi umumnya terdeteksi di stasiun dekat muara Sungai Cimanuk dan stasiun yang berlokasi dekat dengan daratan. Hal ini menunjukkan bahwa sumber antropogenik berasal dari daratan yang dibawa oleh air sungai. Beberapa logam terdeteksi berada di atas nilai ISQG, yang berpotensi memberikan pengaruh negatif terhadap organisme akuatik.

\section{Persantunan}

Penelitian ini didanai oleh Riset Prioritas Kedeputian 2017. Ucapan terima kasih kami sampaikan kepada Bapak Abdul Rozak dan Bapak M. Taufik Kaisupy atas bantuan analisis konsentrasi logam berat di laboratorium.

\section{Daftar Pustaka}

Abowei, J. F. N. (2009). Salinity, dissolve oxygen, $\mathrm{pH}$ and surface water temperature conditions in Nkoro River, Niger Delta, Nigeria. Advance Journal of Food Science and Technology, 2(1), 36 - 40. Retrieved from https://maxwellsci.com/print/ajfst/v26-11.pdf

ATSDR (2019) Agency for Toxic Substances and Disease Registry.Toxicological Profile for Lead. In: Draft for Public Comment. U.S. Department of Health and Human Services, Atlanta, GA.

ATSDR (2012) Agency for Toxic Substances and Disease Registry. Toxicological Profile for Cadmium. U.S. Department of Health and Human Services, Atlanta, GA.

Adeniji, C. A, \& Okedeyi, O.O. (2017). Preliminary assessment of heavy metal concentrations in selected fish feed ingredients in Nigeria. Journal of Fisheries \& Livestock Production, 5(1). https:// doi.org/10.4172/2332-2608.1000218

Aditriawan, R. M., \& Rahardjo, M. F. (2016). Keberadaan logam berat $(\mathrm{Hg}, \mathrm{Pb}$ dan $\mathrm{Cd})$ pada ikan dan sedimen di Muara Cimanuk, Kabupaten Indramayu. Dalam: Zahid, A., Simanjuntak, C. P. H., Lusiastuti, A. M., Rahardjo, M. F., Hadiaty, R. K., Hadie, W., dan Hadie, L. E. (Eds). Prosiding Seminar Nasional Ikan ke-9. Masyarakat Iktiologi Indonesia, 24 Mei 2016, Jakarta: 453 - 461.

Australian and New Zealand Environment and Conservation Council (ANZECC) and Agriculture and Resource Management Council of Australia and New Zealand (ARMCANZ). (2000). Australian and New Zealand guidelines for fresh and marine water quality. Volume 1, Australian and New Zealand Environment and Conservation Council. Canberra. 29p.

Ayangbenro, A. S., \& Babalola, O. O. (2017). A new strategy for heavy metal polluted environments: A review of microbial biosorbents. International Journal of Environmental Research and Public Health, 14(1), 94.

https://doi.org/10.3390/ijerph14010094 
Baran, A., Hersztek, M. M., Gondek, K., Tarnawski, M., Szara, M., Gorczyca, O, \& Koniarz, T. (2019). The influence of the quality of sediment organic matter on the potential mobility and toxicity of trace elements in bottom sediment. Enviromental Geochemistry and Health, 41, 2893-2910. https://doi.org/10.1007/s10653-019-003597

Batley, G. E. \& Gardner, D. (1977). Sampling and storage of natural waters for trace metal analysis. Water Research, 11(9), 745-756. https://doi.org/10.1016/0043-1354(77) 90042-2

Brady, J. P., Ayoko, G. A., Martens, W. N., \& Goonetilleke, A. (2014). Enrichment, distribution and sources of heavy metals in the sediments of Deception Bay, Queensland, Australia. Marine Pollution Bulletin, 81(1): 248-255. https://doi.org/10.1016/ j.marpolbul.2014.01.031

Budiyanto, F., \& Lestari. (2013). Comparison of adsorption models for $\mathrm{Cd}$ and $\mathrm{Zn}$ in the Berau Delta: water-sediment system. Ilmu Kelautan, 18(3), 127-133. https://doi.org/ 10.14710/ik.ijms.18.3.127-133

Budiyanto, F., \& Lestari. (2014). Distribution of metals in Cisanggarung Estuary sediment, West Java, Indonesia. Marine Research in Indonesia, 39(1), 23-30.

https://doi.org/10.14203/mri.v39i1.90

Budiyanto, F., \& Lestari. (2017). Temporal and spatial distribution of heavy metals in sediment of urban coastal water: A case study in Jakarta Bay, Indonesia. Bulletin of the Marine geology, 32(1), 1-10.

https://doi.org/10.32693/bomg.32.1.2017.3 64

Carolin, C. F., Kumar, P. S., Saravanan, A., Joshiba, G. J., \& Naushad, M. (2017). Efficient techniques for the removal of toxic heavy metals from aquatic environment: A review. Journal of Environmental Chemical Engineering, 5(3), 27822799. https://doi.org/10.1016/j.jece.2017. 05.029

CCME.(2001). Sediment quality guidelines. Canadian Environmental Quality Guidelines: 2 pp.

Doelsch, E., Kerchove, V. V. D., \& Macary, H. S. (2005). Heavy metal content in soils of reunion (Indian Ocean). Geoderma, 134 (12), 119-134. https://doi.org/10.1016/j. geoderma.2005.09.003

Duodu, G. O., Goonetilleke, A., \& Ayoko, G. A. (2017). Potential bioavailability assessment, source apportionment and ecological risk of heavy metals in the sediment of Brisbane River estuary, Australia. Marine Pollution Bulletin, 117 (1-2), 523-531.

https://doi.org/10.1016/j.marpolbul.2017.02 .017

Eddiwan. (2018). Pemantauan Kadar Logam Berat dalam air laut dan sedimen di Perairan Pulau Tebing Tinggi, Kabupaten Kepulauan Meranti, Provinsi Riau. Asian Journal of Environment, History and Heritage, 2(1), 7-17. Retriever from http://spaj.ukm.my/ajehh/index.php/ajehh/a rticle/view/43

Fu, J., Hu, X., Tao, X., Yu, H., \& Zhang, Z. (2013). Risk and toxicity assessments of heavy metals in sediments and fishes from the Yangtze River and Taihu Lake, China. Chemosphere, 93(9), 1887-1895.

https://doi.org/10.1016/j.chemosphere.2013 .06 .061

Fuge, Ron. (2013). Anthropogenic Sources. In: O. Selinus et al., (eds). Essentials of Medical Geology: Revised edition. Springer, Dordrecht: 59 - 74 .

Gitarama, A. M., Krisanti, M., \& Agungpriyono, D. R. (2016). Komunitas makrozoobentos dan akumulasi kromium di Sungai Cimanuk Lama, Jawa Barat. Jurnal Ilmu Pertanian Indonesia, 21(1), 48-55. https://doi.org/10.18343/jipi.21.1.48

Gupta, B., Kumar, R., Rani, M., \& Agarwal, T. (2012). Dynamics of toxic heavy metals in different compartments of a highly urbanized closed aquatic system. Journal of Environmental Monitoring, 14, 916-924. https://doi.org/10.1039/c2em10505e

Hutagalung H.P., Setiapermana, D., \& Riyono, S.H.(1997). Metode analisis air laut, sedimen dan biota.Jakarta, Indonesia: LIPI.

Hutagalung, H. P. (1984). Logam berat dalam lingkungan laut. Oseana, IX (1), 11-20.

Ismail, A., Toriman, M. E., Juahir, H., Zain, S. M., Habir, N. L. A., Retnam, A., Kamaruddin, M. K. A., Umar, R., \& Azid, A. (2016). Spatial assessment and source identification of heavy metals pollution in surface water using several chemometric techniques. Marine Pollution Bulletin, 106(1-2), 292-300. https://doi.org/10. 1016/j.marpolbul.2015.10.019

Ke, X., Gui, S., Huang, H., Zhang, H., Wang, C., \& Guo, W. (2017). Ecological risk assessment and source identification for heavy metals in surface sediment from the Liaohe River protected area, China. Chemosphere, $\quad 175, \quad 473-481$. 
https://doi.org/10.1016/j.chemosphere.2017 .02 .029

Kepmen PU. (2010). Keputusan Menteri Pekerjaan Umum No 267/KPTS/M2010 Tentang Pola Pengelolaan Sumber Daya Air Wilayah Sungai Cimanuk Cisanggarung. pp 92

Kumar, C. S., M. Jaikumar, R. S. Robin, P. Karthikeyan, \& C. S. Kumar. (2013). Heavy metal concentration of sea water and marine organisms in Ennore Creek, Southeast Coast of India. The Journal of Toxicology and Health. Photon, 103, 192201.

KMNLH.(2004). Keputusan Menteri Negara Kependudukan dan Lingkungan Hidup No Kep-51/MNKLH/I/2004 Tentang Pedoman Penetapan Baku Mutu Air Laut, Menteri Negara Kependudukan dan Lingkungan Hidup, Jakarta: 10 - 12

Lestari \& Witasari, Y.(2010). Logam berat di perairan di Teluk Lampung. Bunga Rampai Sumberdaya Laut dan LingkunganTeluk Lampung. Jakarta, Indonesia: Pusat Penelitian Oseanografi LIPI.

Li, Y., \& Ren, S. (2011). Metal Decorative Materials. In Building Decorative Materials.169 - 199. https://doi.org/10.1533 19780857092588

Liu, J., Yin, P., Chen, B., Gao, F., Song, H., \& Li, M. (2016). Distribution and contamination assessment of heavy metals in surface sediments of the Luanhe River Estuary, northwest of the Bohai Sea. Marine Pollution Bulletin, 109(1), 633-639. https:// doi.org/10.1016/j.marpolbul.2016.05.020

Liu, R., Men, C., Liu, Y., Yu, W., Xe, F., \& Shen, Z. (2016). Baseline: Spatial distribution and pollution evaluation of heavy metals in Yangtze estuary sediments. Marine Pollution Bulletin, 110(5), 564-571. https://doi.org/10.1016/j.marpolbul.2016.05 .060

Loring, D. H., \& Rantala, R. T. T. (1992). Manual for the geochemical analyses of marine sediments and suspended particulate matter. Earth-Acience Reviews, 32(4), 235-238. https://doi.org/10.1016/0012-8252(92) 90001-A

Macomber, L., \& Hausinger, R. P. (2011). Mechanisms of nickel toxicity in microorganisms. Metallomics, 3(11), 1153-1162. https://doi.org/10.1039/c1mt00063b

Magnusson, B., \& Westerlund, S. (1981). Solvent extraction procedures combined with backextraction for trace metal determinations by
Atomic Absorption Spectrometry. Analytica Chimica Acta, 131(1), 63-72. https://doi.org/10.1016/S0003-2670(01) 93534-2

Mohammed, A. S., Kapri, A.,\& Goel, R. (2011). Heavy Metal Pollution: source, impact and remedies. In: Khan et al., (eds). Biomanagement of metal-contaminated soils(pp. 1-28). Environmental Pollution. https://doi.org/10.1007/978-94-007-19149_1

Natalina \& Firdaus, H. (2017). Penurunan kadar kromium heksavalen (Cr6+) dalam limbah batik menggunakan limbah udang (kitosan). Teknik, 38(2), 99-102. https://doi.org/ 10.14710/teknik.v38n2.13403

Peng, J.F., Song, Y. H., Yuan, P., Cui, X. Y., \& Qiu, G. L. (2009). The remediation of heavy metals contaminated sediment. Journal of Hazardous Material,161(2-3), 633-640. https://doi.org/10.1016/j.jhazmat. 2008.04.061

Peng, W., Li, X., Xiao, S., \& Fan, W. (2018). Review of remediation technologies for sediments contaminated by heavy metals. Journal of Soils and Sediments.18(4), 1701-1719. https://doi.org/10.1007/s11368-018-1921-7

Riwayati, I., Hartati, I., Purwanto, H., \& Suwardiyono. (2014). Adsorpsi logam berat timbal dan kadmium pada limbah batik menggunakan biosorbent pulpa kopi terxanthasi.Dalam: Fakultas Teknologi Industri IST AKPRIND (Eds). Prosiding Seminar Nasional Aplikasi Sains \& Teknologi(SNAST) 2014. Institute Sains \& Teknologi AKPRIND, 15 November 2014, Yogyakarta: C211 - C216.

Rosado, D., Usero, J.,\& Morillo, J. (2016). Assessment of heavy metals bioavailability and toxicity toward Vibrio fischeri in sediment of the Huelva estuary. Chemosphere,153, 10-17. htpps://doi.org/ 10.1016/j.chemosphere.2016.03.040

Rumahlatu, D. (2011). Konsentrasi logam berat kadmium pada air, sedimen dan Deadema setosum (Echinodermata, Echinoidea) di Perairan Pulau Ambon. Ilmu Kelautan, 16(2), 78-85. Retriever from https:// ejournal.undip.ac.id/index.php/ijms/article/ viewFile/1850/1611

Saher, N. U. \& Siddiqui, A. S. (2019). Occurrence of heavy metals in sediment and their bioaccumulation in sentinel crab (Macrophthalmus depressus) from highly impacted coastal zone. Chemosphere, 221, 89-98. 
htpps://doi.org/10.1016/j.chemosphere.201 9.01.008

Setyawan, W. B. (2017). Potensi bencana geologi di kawasan Delta Cimanuk, Kabupaten Indramayu, Jawa Barat. Dalam: M. Taufiqurrohman, Dwisetiono, Subagio, H., Widagdo, H., \& Suwasono, B. (Eds). Seminar Nasional Kelautan XII (hal. 1424). Surabaya: FTIK, Universitas Hang Tuah.

Suresh, S.G. P., Ramasamy,V., \& Venkatachalapathy, R. (2012). Assessment of spatial distribution and potential ecological risk of the heavy metals in relation to granulometric content of Veeranam lake sediments, India. Ecotoxicology and Environmental Safety, 84, 117-124. htpps://doi.org/10.1016/j. ecoenv.2012.06.027

Sutherland, RA. (2000). Bed sediment-associated trace metals in an urban stream, Oahu, Hawaii. Environmental Geology,39(6), 611-627.

htpps://doi.org/10.1007/s002540050473

Sutriati, A. (2011). Penilaian kualitas air sungai dan potensi pemanfaatannya studi kasus: $\mathrm{S}$. Cimanuk. Jurnal Sumber Daya Air, 7(1), 117. htpps://doi.org/10.32679/jsda.v7i1.378

Tampubolon, P. A. R. P., Ernawati, Y., \& Rahardjo, M. F. (2018). Keragaman iktiofauna muara sungai Cimanuk, Indramayu, Jawa Barat. Berita Biologi,17(1), $39-48$. https://doi.org/10.14203/ beritabiologi.v17i1.1331

Tang, A., R. Liu, M. Ling, L. Xu, \& J. Wang. (2010). Distribution characteristics and controlling factors of soluble heavy metals in the Yellow River Estuary and adjacent sea. International Society for Environmental Information Science, 2, 1193-1198. https://doi.org/10.1016/j.proenv.2010.10.12 9

Taylor, S.R., (1964). Abundance of chemical elements in the continental crust: a new table. Geochimica Cosmochimica Acta, 28(8), 1273-1285. https://doi.org/10 $.1016 / 0016-7037(64) 90129-2$

USEPA.(1996). Test Methods for Evaluating Solid Waste SW-846 Methods 3050B.

Vandecasteele, B., Samyn, J., Quataert, P., Muys, B., \& Tack, F. M. G. (2004). Earthworm biomass as additional information for risk assessment of heavy metal biomagnification: a case study for dredged sediment-derived soils and polluted floodplain soils. Environmental Pollution, 129(3), 363-375. htpps://doi.org/10. 1016/j.envpol.2003.12.007

Varol, M. (2011). Assessment of heavy metal contamination in sediments of the Tigris River (Turkey) using pollution indices and multivariate statistical techniques. Journal of Hazardous Materials, 195, 335-364. htpps://doi.org/10.1016/j.jhazmat.2011.08.0 51

Vu, C. T., Lin, C., Shern, C. C., Yeh, G., Le, V. G., \& Tran, H. T. (2017). Contamination, ecological risk and source apportionment of heavy metals in sediments and water of a contaminated river in Taiwan. Ecological Indicators, 82, 32-42. htpps://doi.org /10.1016/j.ecolind.2017.06.008

Waldichuck, S.J. (1974). Some biological concern in metal pollution. In: Venberg and Venberg (Eds). Pollution and physology of marine organisms (pp. 1-45). London, England: Acad. Pres.. 